\title{
Germplasm and Incentives for Boosting Coconut Production: Case Studies from the Pacific Region and Some Other Countries
}

\author{
Roland Bourdeix ${ }^{(1,2)}$, Nat Tuivavalagi ${ }^{(3)}$, Victor Mataora ${ }^{(4)}$, Augustine B Jerard ${ }^{(5)}$, and \\ Naheed Hussein ${ }^{(6)}$.
}

\begin{abstract}
Summary
The Coconut Industry Development for the Pacific Project (CIDP) is a joint initiative of the Pacific Community, the European Union and the African, Caribbean and Pacific Group of States. The aim of CIDP is to bolster the coconut sector in the region through improving the competitiveness of small producers and strengthening production and regional integration of related markets. In the framework of this project, CIRAD (French Agricultural Research for Development) was in charge of helping design improved seed production systems and conducting a risk analysis for coconut value chain in the Pacific region. During a meeting held in April 2018 in Fiji, thirty participants from sixteen countries and territories in the Pacific region participated to a brainstorming on incentives for boosting coconut production. In June 2018, CIRAD launched an online survey on the same topic by contacting more than a thousand of coconut stakeholders worldwide. This communication presents the first results of these two initiatives regarding incentives for boosting coconut production, in the Pacific region but also in comparison with countries from other regions.
\end{abstract}

\section{Acknowledgements}

The authors would first like to thanks all the participants of the CIDP meeting held from $17^{\text {th }}$ to $20^{\text {th }}$ April 2018 in Nadi, Fiji, who participated to the brainstorming on incentives, namely: Teava Iro , Victor Mataora (Cook Islands); David Dore, Stephen Hazelman, Naheed Hussein, Isikeli Karikaritu, Lavinia Kaumatotoya, Peter Kjaer, Vijendra Kumar, Moana Masau, Roneel Prasad, Osea Rasea, Soane Remudu (Fiji); Jerome Lecerf (French Polynesia); Nacanieli Tuivavalagi (FSM); Philippe Visintainer (Hawaii); Ieete Timea (Kiribati); Bern Dowouw (Nauru); James Poihega (Niue); Omeliakl Smus (Palau); James Maora (PNG); Karness Kusto, Stephen Lepton (RMI); Robert Tautua (Samoa); Roy Vaketo, Franklyn Wasi (Solomon); Tevita Fonokalafi, Viliami Kato (Tonga); Uatea Vave (Tuvalu); Baroroa Italio and Tiata Sileye (Vanuatu). Some researchers also provides useful advices for launching the online survey, namely: Luc Baudouin, Claire Billot, Xavier Bonneau, Selim Louafi, Jean Pierre Labouisse, Jean Ollivier, (CIRAD), Vincent Johnson (Bioversity International), and Jessie Lin (University of Gottingen). The 49 coconut stakeholders who replied the online survey should also be acknowledged. It is expected than some of these, together with some other people cited up, will participate as contributors in the coming publication "Coconut Risk Management and Mitigation Manual for the Pacific Region".

(1) CIRAD, UMR AGAP, F-34398 Montpellier, France.

(2) AGAP, Univ Montpellier, CIRAD, INRA, Montpellier SupAgro, Montpellier, France.

${ }^{(3)}$ Cooperative Research and Extension (CRE) Division, College of Micronesia-FSM.

(4) Ministry of Agriculture, Cook Islands.

${ }^{(5)}$ ICAR-Central Island Agricultural Research Institute, Andaman and Nicobar Islands, India.

${ }^{(6)}$ Secretariat of the Pacific Community, Suva, Fiji. 


\section{Introduction}

The project "Coconut Industry Development for the Pacific Project" (CIDP) is a joint initiative of the Pacific Community, the European Union and the African, Caribbean and Pacific Group of States. The aim of CIDP is to bolster the coconut sector in the region through improving the competitiveness of small producers and strengthening production and regional integration of related markets.

In the framework of this project, the CIRAD (French Agricultural Research for Development) has been in charge of helping in designing improved seed production systems and conducting a risk analysis for coconut value chain in the Pacific region. The CIRAD contribution included the implementation a regional "train the trainer's workshop" covering all relevant aspects of coconut Production and Seeds System in the Pacific Region.

Thirty participants from sixteen countries and territories in the Pacific region participated to this workshop held from $17^{\text {th }}$ to $20^{\text {th }}$ April 2018 in Nadi, Fiji ${ }^{1}$. During this meeting, two additional initiatives were developed:

- A brainstorming session was devoted to incentives for boosting coconut sector

- All participants agreed on a list of 24 regional technical recommendations on coconut cultivation and planting material (Bourdeix et al., 2018a).

In July 2018, in the framework of the risk analysis study, CIRAD also launched an online survey dedicated to both incentives and risks in coconut value chain. This paper summarizes the

\footnotetext{
${ }^{1}$ They gather technical officers from the Ministries of Agriculture, members of NGOs, researchers and staff of SPC and CIRAD, and managers of farms and private companies from the following countries and territories: Cook Islands, Fiji, France, Federated States of Micronesia, Kiribati, Marshall Islands, Nauru, Niue, Palau, Papua New Guinea, Samoa, Solomon, Tonga, Tuvalu, Vanuatu, French Polynesia and Hawaii.
}

results of these three interactions, focusing on incentives for boosting coconut sector and seed production systems.

\section{Material and methods}

Together with the field's visits conducted in five Pacific countries, the meeting also allowed to collect and exchange useful information about seed production systems and related incentives in the Pacific region. Part of this information is presented hereunder in the case studies.

\section{Brainstorming on Incentives conducted during the Nadi meeting}

A three hours section was devoted to this brainstorming. Participants were divided into three approximately equal groups. Each group was asked to exchange for 90 minutes about the situation in participant' country and to imagine systems and incentives that could improve the coconut sector. Then, during 90 more minutes, the three groups presented their results, with the help of three facilitators; two acting orally, the other writing the ideas directly in a Word document projected in the room.

\section{Launching a short online survey on incentives and risks in coconut value chain}

The draft online survey was sent for advices to about ten researchers from CIRAD, Bioversity International, SPC and other institutions. We analysed their replies and took into accounts most of their comments. Many colleagues were in favour of extending the questionnaire, but we did not choose this option. It seemed preferable to propose a very short questionnaire, and then eventually ask for more information and more participation from those who provided significant answers. The survey finally contains only five questions, available in English, French and Spanish languages:

1. In your opinion, what are the main risks or constraints in coconut cropping and valuechain? Please cite 3 and classify them by priority order

2. In your opinion, what could be the most efficient incentives to boost coconut sector? These incentives can be designed 
for farmers or for any other stakeholders of the coconut value chain. Please cite three and classify them by priority order.

3. In which country are you living?

4. Are you: a farmer, a tropical gardener or landscaper, a local coconut reseller, an agricultural officer, a researcher, a policy maker, a coconut consumer, a craftsman processing coconuts, from a small company selling coconut product, from a large one, from a company selling coconut processing equipment, or other.

5. Your email (optional). It will allow our team to contact you and you will receive the result of this survey.

The survey presentation and links were included as a new publication in the website "http://replantcoconut.blogspot.com". We proposed to way of reply, directly online via Kobotoolbox $^{2}$, or by filling a Word version of the questionnaire and send it back to a dedicated Email address.

We first constituted lists of emails from the expert's list of contact, from the APCC Directory of Coconut Traders and Equipment Manufacturers and from the COGENT network. From these sources, we created a diffusion list containing about 2400 Emails $^{3}$.

A first message asking stakeholders to reply the survey was sent both via this diffusion list and on the coconut google group on June $20^{\text {th }}$ 2018. Advertisement about the survey was done on LinkedIn (free, using dedicated groups) and Facebook (audience targeted on agriculture and coconut palm in 20 English-speaking countries, from 16 to 20 July). The same information was sent via the Email diffusion list on July $16^{\text {th }}$ 2018.

\footnotetext{
${ }^{2}$ Technical note for remembering: for Kobotool box, results can be exported as CSV files, and transferred to Excel.

${ }^{3}$ Technical note for remembering. Internal link to the diffusion list: http://sympa.cirad.fr/sympa/info/prag08
}

As some colleagues told us they were unable to visit the website, the message was sent again to the coconut google group on July $31^{\text {st }}$ 2018 , with a word version of the questionnaire as attached file. Some of the respondents could become associated authors of some relevant section of the coming risk analysis manual.

\section{Results}

We conducted a balance of incentives and seed production systems in 15 countries and territories of the Pacific region, plus 2 other countries as comparison, as of April 2018. Here is the summary of these 17 country case studies, of which two outside the Pacific region (India and Thailand), and 15 inside (Cook Islands, Federated States of Micronesia (FSM), Fiji, French Polynesia, Hawaii, Kiribati, Marshall Islands, Nauru, Papua New Guinea, Palau, Samoa, Solomon Island, Tonga, Tuvalu and Vanuatu). Then we present the results of the brainstorming conducted during the CIDP Nadi meeting and the online survey.

\section{Case studies in the Pacific region}

\section{Cook Islands}

In 2018, a limited amount of Tall-type seedlings was provided free to farmers, who do not receive any incentive for replanting. There is no follow up of the planted coconut palms. Following fields visit, the expert made the proposal to give to farmers 1 NZD for each coconut palm planted, and 1 or 2 NZD more if the coconut survive after one year. Local agricultural officers were in opinion that these incentives would not be very useful, as this small amount will not be sufficient to influence farmer's decisions. Nevertheless, this kind of incentive could be useful in schools, for local programs dealing with students and relayed by teachers. A new idea came out. We made demonstration of the coconut harvest hook/sickle that allows to cut the entire bunch by sectioning the peduncle, and harvest twice more rapidly than the existing system. Such hook is not for sale in the Cook. Many people in Atiu and Rarotonga islands showed interest in this hook and asked to keep it. Therefore, the new idea is to launch a communication action advising: plant 
20 coconut palms and receive a special coconut hook/sickle that allow harvesting the coconut very rapidly. This will have the double advantage to provide an incentive for replanting and to diffuse a more efficient harvest method.

Federated States of Micronesia (FSM), Marshall Islands, Nauru, Palau and Tuvalu.

According to the participants of the CIDP Nadi meeting, no seednuts are released to farmers by any institution, no incentive is provided from government for replanting. In Marshall Islands, some private company is releasing incentives for coconut farmers (no more information available). In Nauru in 2014, farmers received 500 seedlings. In FSM, the government provided incentives in the1980's, but no more.

\section{Fiji}

Up to August 2018, the Ministry of Agriculture provided free seednuts and/or seedlings to farmers, with no incentive for replanting, and no follow up of the planted coconut palms. The seednuts provided were Fiji Tall and Rotuman Tall, the hybrid between Malayan red Dwarf and Rotuman Tall (just beginning again, not organic), and a few Malayan-type Dwarf varieties. A private fellow is selling Rotuma Tall seednuts for 10 FJD per unit on Facebook. In addition, farmers benefit subsidies on mineral fertilizers, the farmer pay one third and the government two third.

A Coconut Development Program conducted in Vanua Levu Island in 2014-2015. Observations conducted by the first author of this paper (Bourdeix, 2018b) indicated that:

- $\quad$ The only data available (or accessible) was lists of farmers by district, containing only the farmer's names and a number of released seednuts. We were lucky to find again one of the officer in charge of the program, who remembered where a few of these farmers were located.

- We tried to visit six farmers and we succeed to meet three. For these few farmers, no more than $40 \%$ of the released seednuts were planted and remains as living palms in the field.

- All these farmers were located inland, cultivate sugarcane and plant coconut palms only around their sugarcane fields. None of these farmers releases coconut to the industry (auto consumption). We had confirmation that, in 2014-2015, seednuts were delivered only to these sugarcane farmers'. Therefore, it could be presumed that the development plan conducted during the years 2014-15 in Vanua Levu seems to have no effect on coconut industry but assisted in self-consumption.

A nursery managed by the company Copra Millers of Fiji Ltd was also visited in 2018. It was learnt that the company was facing reduced supply of coconuts for its factory due to poor yields from senile palms of the traditional coconut areas and hence has decided to support new planting and replanting through supply of quality seedlings to the coconut growers. The company was releasing about 5000 seedlings per year. Officers from the Ministry's Extension Service select the parent palms and help in bringing the seednuts to the company's nursery. The nursery had a medium management status (weeds that could induce diseases). Some of the germinating sprouts were of yellow and red/orange colours indicating that, very probably, some of the selected parent palms were not Tall types but Dwarf $\mathrm{x}$ Tall hybrids. Such parent palms should be avoided; true-totype hybrids from Taveuni should also be proposed to farmers. Despite these small technical issues, in the expert opinion, this nursery seemed particularly interesting, because the seedlings were delivered to farmers who come to the company to sell their products: in this case, coconut industry will benefit from the new plantations. Following this analysis, the incentive program in Fiji has evolved (see the conclusion of this paper).

\section{French Polynesia}

Non-organic Dwarf $\mathrm{x}$ Tall Hybrid seedlings (Brazilian Green Dwarf x Rangiroa Tall) are produced in Raiatea Island. They are sold at about two USD per seedlings to farmers. 
Cooperatives and NGOs are releasing incentives for replanting. The local government is providing fixed price of copra and free transportation. A four-year subsidy program is conducted with cooperatives and NGOs. The incentive is two USD per planted palm, with partial follow up of living palms. Protection against rats and solar drier for copra are sold at a subsidy rate. For biological control of Brontispa, the agricultural services freely provides Tetracyclus bees to farmers.

\section{Hawaii}

No incentive for replanting, all market for planting material is private. Coconut seedlings are sold online for USD \$39.99. A private fellow is selling special Dwarf seedlings at 100 USD per unit. In 2018, a large USDA program is providing USD $2,323,880$ to respond to the Oryctes beetle infestations in Hawaii and Guam (Powel and Bond, 2018). No information available on funding and incentives dedicated to planting material in this program.

\section{Kiribati}

As of 2018, Tall-types seednuts and/or seedlings provided free to farmers, no incentive for replanting, no follow up of the planted coconut palms. Very recently, an agricultural officer launched an original kind of "cultural" incentives orientated towards young farmers in Abaiang Island: he launched a soccer coup, the participation of which was linked to the prior plantation of a certain number of coconut palms by youths.

\section{Papua New Guinea}

The CCRI (Cocoa \& Coconut Research Institute) is producing non-organic Dwarf $\mathrm{x}$ Tall hybrid seednuts from its seed gardens. Tall-types seednuts are bought one Kina from farmers. CCRI raises both hybrids and Talls in the nursery and provide free seedlings to farmers. There is no systematic follow up after planting. Cooperative societies and schools provides some incentives on equipment for planting (Knife, etc.).

\section{Samoa}

Tall-type seednuts bought by the Ministry of Agriculture and Fisheries (MAF) at 0.5 WST per seednut. Once germinated, seedlings are then re-sold to farmers for 0.2 WST per piece. Other seednuts (Dwarfs, seednuts harvested from hybrids sold as hybrids) are provided by Nuu Research Station from limited number of parent palms. Activities proposed by CIDP aims to diversify the planting material and to increase the quality and quantity of available seednuts. The Stimulus Package program, that will end in 2018, consisted in: the farmers who own at least 2 acres pay 100 WST and then receive planting material (coconut, cocoa and fruit trees), plus technical advices from officers of the Ministry of Agriculture. It seems that another option of the stimulus package was also applied in 2016: fiftythree farmers received a first bonus of up to WST 1,000 after registering in the incentive with the balance of WST 3,000 to be paid out in the next three years depending on their performances and compliance with the requirements (Tuiletufuga, 2016).

\section{Solomon Islands}

From the 2000's, the Ministry of Agriculture is no longer directly releasing seednuts of seedlings to farmers. From 2004, the company KoKonut Pacific Solomon Island (KPSI) constituted farmer's groups for use of the Direct Micro Expelling (DME) technology for production of virgin coconut oil. This company now works collaboratively with over 600 certified organic farms in the Solomon Islands, with almost 40 village-based DME® processors installed on height provinces (Malaita, Makira, Central Islands, Isabel, Western, Guadalcanal, Temotu and Choiseul). In October 2016, KPSI started to implement a 200-hectare-coconutreplanting program funded by the Ministry of Agriculture and Livestock. The fund provides incentives and cash money for those doing replanting. At the nursery stage: SBD 4 per sown coconut; after field planting - SBD 5 per seedlings planted. Follow up of young plantation was conducted during annual organic certification. Providing planting material to suppliers strongly increase the probability that 
their production will benefit the coconut industry. The company selected twenty DME sites. Each selected DME had to designate 10 farmers, each of them replanting one hectare (200 coconut in nursery and 160 seedlings to be planted in the field). Farmers select the seednuts in their own farm on criteria that are not well established, mainly healthy palms with large fruits. It seems that some of them simply take the forgotten germinated coconut in their fields.

\section{Tonga}

According to the participants of the CIDP Nadi meeting, there is financial incentive for replanting in Tonga. Ministry is collecting the seednuts from government properties or buying from private farmers ( 0.45 FJD); raise seedlings and provide them free to farmers. Officers are going to the fields for plantation but further no follow up. Expert visit to Tonga was cancelled due to cyclonic conditions. It seems that another expert made recommendations about improving the coconut seed system in Tonga, but Tongan participants were unable to provide further information during the meeting.

\section{Vanuatu}

The Vanuatu Agricultural Research and Technical Centre (VARTC) is producing nonorganic seednuts of improved Vanuatu Tall (VTT) in Santo Island. The Department of Agriculture and Rural Development (DARD) release these seednuts free to farmers by. Partial follow up of the planted coconut palms by local officers. The three activities initially proposed under CIDP aims to diversify the planting material, to amplify the impact of the present governmental scheme, and to decentralize seed production. It planned to establish a first list of potential farmers from who neighbouring farmers will be able to source Improved VTT in other islands. Some large estates could serve as nucleus farms to boost the planting material dissemination.

\section{Case studies from other countries}

\section{India}

The Coconut Development Board (have developed scheme of incentives, including production and distribution of planting material, expansion of area under coconut, integrated farming for productivity improvement, and coconut processing units. CDB have established seven Demonstration cum Seed Production (DSP) Farms in different parts of the country (total $240 \mathrm{ha}$ ) with the aim to produce quality seednuts (CDB, 2018). Coconut nurseries from these farms produce quality seedlings of desired cultivars/varieties, suitable for each locality, and distribute them to farmers at reasonable price.

A financial assistance is provided to registered/ private/ approved coconut nurseries. This assistance is limited to $25 \%$ of the cost of production or Rs.2 lakhs whichever is less. The minimum financial assistance of Rs.50000 is allocated for producing 6250 seedlings annually from 25 cents and maximum financial assistance of Rs.2 lakhs for producing 25000 seedlings from one acre. The maximum financial assistance for setting up of regional coconut nursery in non-traditional areas is 50\% of cost of production. Maximum financial assistance is limited to Rs.6 lakhs to establish seed garden phased over a period of 3 years @ Rs.3 lakhs during the 1st year and Rs.1.50 lakhs each in second and third year respectively. The quantum of financial assistance is based on the total area of seed garden (maximum 4 ha) or limited to $25 \%$ of the cost of establishment of nuclear seed garden.

CDB provides incentive assistance to small and marginal farmers for undertaking new planting of coconut and its further maintenance. The new planting assistance is given at the rate of Rs. 8,000 per hectare, which is disbursed in two equal annual instalments. Financial assistance of Rs.35,000 per ha in two annual instalments is provided for adoption of integrated management practices in disease affected gardens. To promote the use of organic manure like vermicompost, coir pith compost, ordinary compost and FYM in coconut holdings, CDB provides a financial assistance of Rs.20000 per unit or $50 \%$ of cost of production for setting up of a unit.

The incentives provided to farmers are as follows: half of the cost of land preparation, cutting and removal of senile palms (Rs.500per 
palm); a quarter of the cost of rejuvenation (Rs.15000 per hectare over a period of 2 years); and half of the cost of replanting (Rs.20 per seedling).

The Indian private coconut seed market is flourishing. In 2018, farmers have to pay and wait for eight months to get hybrids seedlings produced by private farms and sold at Rs.450 (6.45 USD). A private company from Solomon Islands recently bought Dwarf $\mathrm{x}$ Tall hybrid seedlings cultivated in vitro from India at the price of 10 USD per unit (Rev. Vernon Smith, 2018, personal communication).

Large chunk of money has been provided by Government agencies in India in the form of subsidy to farmers for installing micro irrigation methods including drip irrigation and coconut basin management.

The Indian government recently launched a subsidy scheme for coconut producing units. The financial assistance is limited to $25 \%$ of the project cost but not exceeding Rupees 50 Lakh for infrastructure development, establishment or modernization and up gradation of coconut based processing units under the scheme. The promoter has to avail at least $40 \%$ of the project cost as term loan from a bank or financial institutions of his choice. Refinement of traditional processing methods including quality certification, micro-filtering, branding could be considered as value addition in the case of coconut oil and virgin coconut oil and considered for assistance under the scheme.

\section{Thailand}

About 50 to 60 years ago, Thai growers identified a variety of coconut for water consumption that carries special fragrance. In 2010, the Thai Government consolidated the 'Aromatic Coconut' industry as a new agricultural industry and separated it from the 'mainstream' coconut industry (Krisanapook, 2015). Thai Government organization also setup new strategies and approved a new budget of 118 million baht (US\$4 million). The new strategies support the 'Aromatic Coconut' industry in four structural changes: 1) plans to increase production; 2) product development and diversity; 3) organization support; and 4) market development. The new strategies also setup new legislation that 'Aromatic Coconut' propagation and plantation must be kept inside the country, banning seednuts exportation. However, 'Aromatic Coconut' is presently grown in many countries. Seednuts of Aromatic Green Dwarf are sold online (eBay) from Thailand for US $\$ 40$ each, although the government normally ban it. Fields visit conducted in 2018 by R. Bourdeix in the Ratchaburi region indicated that some local farmers are selling important lots of seednuts to Thai resellers who export them to neighbouring countries.

In 2010, there was a big invasion of coconut Hispine Beetle (Brontispa longissima Gestro) in the coconut growing area in the southern region of Thailand. This later spread to other regions, including some areas in the main growing area of 'Aromatic Coconuts'. The beetle destroyed about 40,000 hectares of coconut plantations in 19 provinces. In 2012, coconut black-headed caterpillar (Opisina arenosella) also destroyed many palms. Although many Thai growers still apply chemicals in combating coconut pests and insects, few growers avoid chemicals and develop bio-control methods in their coconut plantations. Government support organizations used to provide parasite insects to the coconut growers. Over the years, the demand has increased significantly. Now government organizations setup training and help growers raise their parasitic insects by themselves. Few growers develop it further and raise these insects to other growers.

In 2018, price paid to farmers was 6-8 Bath per coconut ( 0.15 to 0.21 Euros) during the best season and up to 15 Bath (0.39 Euros) during the low production season. We do not have yet the information wither organic coconut are paid better than others. The coconuts contain $320 \mathrm{ml}$ of water in average, but it can fall to 240 $\mathrm{ml}$ if appropriate fertilizers are not applied. Price paid to farmers is about 0.7 Euros per litre, when retailers are selling the aromatic coconut water at more than 10 Euros per litre on USA market. In Bangkok, price of a tender coconut is 40 Bath in 2018. 
Most of coconut plantations produce 140 to 250 green nuts per palm per year. Some local stakeholders indicated a return of about 1000 Euros per hectare. When calculating with 200 fruits per palm, 200 palms per hectare, and 0.21 Euros per fruit, the gross income is up to 8400 Euros per hectare - so the return could be much more than 1000 Euros per hectare. The price of the dedicated agricultural land has grown up to 100,000 Euros per hectare. Many plantations use a canal system between the coconut lines. Farmers throw the harvested nuts into these channels that serve for transportation. They also throw organic waste (leaves, raffles) in these channels. Farmers regularly extract the mud and organic matter from these channels, either manually or with a machine, and deposit it at the foot of the coconut trees to serve as fertilizer. A mixture of rice straw and chicken droppings, at a rate of 20 to $40 \mathrm{~kg}$ per tree per year, serves as additional organic fertilization.

\section{Result of the brainstorming on incentives conducted during Nadi Meeting}

The analysis carried out during the oral presentations of the groups and the following discussion led to define a typology of the incentives and to allocate the suggestions of each group according to categories presented below.

\section{Cited by the three groups:}

- $\quad$ Provide organic certified free seedlings to committed farmers, by ministries or private companies

\section{Cited by two groups:}

- Guaranteed prices of coconut products

- Integrated programs including diversification of crops, intercropping to maximize benefit and increase food security

- Use of technology and release of technical information and tools for increasing production, quality and diversifying coconut products

- Contests, rewards in coconut days or other ceremony
- Contract between coconut farmers and private companies.

- Find a way to avoid cultural dependency of farmers to funding: all activities should not stop when the projects end.

- Help in transportation of coconut products by public or private bodies.

\section{Cited by only one group:}

- Provide basic tools, such as knife, harvest hook/sickle

- Some incentives should be focused on youth and new coconut farmers

- Special incentives towards planting coconut in coastal zones for disaster risk reduction

- Facilitate nursery as a business - Private seed system

- Subsidies, incentives for planting - given preferably before the planting

- Taxes on imported edible oils and all imported coconut products and use revenue to support local coconut industry

- Assistance to exportation, including regional trade agreements.

- Government and private companies to favour sustainable production practices (Organic).

- Support to micro and small enterprises working on high-value coconut products

- Engage traditional chiefs and leaders in the incentive programs

\section{Result of the online survey}

At the date of August $9^{\text {th }} 2018,49$ significant replies where obtained. Respondent are located in 26 different countries or territories: India (10 respondents), Australia and Indonesia (4 in each), Malaysia (3), French Polynesia, Papua New Guinea, Philippines, Tanzania, Tonga, Vanuatu (2 in each); plus one reply for each of the following countries: Brazil, Benin, Côte d'Ivoire, Fiji, Hawaii, Kenya, Nicaragua, Nigeria, Pakistan, Samoa, Seychelles, Solomon Islands, Sri Lanka, Thailand, UK and Vietnam. 
Respondents were mainly researchers (19), farmers (12), policy makers (6), from another category than the listed ones listed or did not reply (5), for a small company involved in coconut sector (4). Three more were local coconut reseller, from a large company and coconut consumer only. We did not take into account multiples replies (for instance both researcher, farmer and consumer) and we focused only on the first one.

We defined a typology by using a two steps process. A first typology was drafted by going through and evaluating all the replies. Second, we refined the typology during the analysis of the individual replies. We finally obtained 11 categories.

Some of the replies went out through the typology. For instance, for the second incentive, the reply "Major national effort in getting the right cultivars into large scale nurseries. Mapping out the correct land for these to be planted in" added a value of one to both the categories "planting material' and "Land".

We conducted twice the repartition of suggested incentives in categories, and we choose the average (highest entire value) of the two notations. We calculated for each category a total (sum of the values obtained as first, second, and third incentives) and a pondered total (first prioritized incentive counted as 3 , second as two, and third as one). The categories were classified according to the pondered total, as shown in table 1 .

The most favoured incentives were those related to planting material (both in total and pondered total); then "Securing farmer's income"; "Land and landscape for coconut cultivation"; "National policies", and "Diversification for higher value of coconut product". Table 2 provides narrative descriptions of

Table 1.

Categorization and prioritization of suggested incentives from the online CIDP survey

\begin{tabular}{|c|c|c|c|c|c|c|}
\hline \multirow{2}{*}{\multicolumn{2}{|c|}{ Categories }} & \multicolumn{3}{|c|}{ Priority } & \multirow{2}{*}{ Total } & \multirow{2}{*}{$\begin{array}{l}\text { Pon- } \\
\text { dered } \\
\text { Total }\end{array}$} \\
\hline & & 1 & 2 & 3 & & \\
\hline 1 & Good planting material for farmers & 18 & 9 & 4 & 31 & 76 \\
\hline 2 & Securing farmer's income & 10 & 5 & 4 & 19 & 44 \\
\hline 3 & Land and landscape for coconut cultivation & 8 & 8 & 3 & 19 & 43 \\
\hline 4 & National policies & 3 & 10 & 10 & 23 & 39 \\
\hline 5 & Diversification for higher value of coconut product & 5 & 8 & 8 & 21 & 39 \\
\hline 6 & $\begin{array}{l}\text { Professionalizing coconut producers and their } \\
\text { organizations. }\end{array}$ & 4 & 5 & 3 & 12 & 25 \\
\hline 7 & Good cultivation practices & 3 & 4 & 7 & 14 & 24 \\
\hline 8 & Pest and diseases & 4 & 2 & 2 & 8 & 18 \\
\hline 9 & Processing from farm to consumers & 2 & 4 & 3 & 9 & 17 \\
\hline 10 & International policies & 1 & 3 & 5 & 9 & 14 \\
\hline 11 & Reducing cost of product transportation & 0 & 1 & 1 & 2 & 3 \\
\hline Total & Total & 58 & 59 & 50 & 167 & 342 \\
\hline
\end{tabular}


Table 2. Rationale and narrative of the incentives typology in link with individual replies

\begin{tabular}{|c|c|c|}
\hline & Categories & Notes on individual incentives proposals \\
\hline 1 & $\begin{array}{l}\text { Good planting } \\
\text { material for farmers }\end{array}$ & $\begin{array}{l}\text { Free of charge seedlings - Provide quality planting material adapted to each region - Train farmers to harvest and prepare themselves best } \\
\text { planting material - Diversify the genetic base of planting material - More nurseries - Promote hybrids - Promote local varieties - Use molecular } \\
\text { approach to improve breeding techniques - Government to support public and/or private coconut breeding programmes and gene banks - While } \\
\text { maintaining bio security, to simplify import and export of planting material. }\end{array}$ \\
\hline 2 & $\begin{array}{l}\text { Securing farmer's } \\
\text { income }\end{array}$ & $\begin{array}{l}\text { Stabilize the selling prices - secured local and international market - Minimum price guaranteed even in situation of oversupply - Insurance } \\
\text { against low prices. Special incentives for insulated and marginal farmers. }\end{array}$ \\
\hline 3 & $\begin{array}{l}\text { Land and landscape } \\
\text { for coconut } \\
\text { cultivation }\end{array}$ & $\begin{array}{l}\text { Devote more and more suitable land for coconut cultivation - Subsidies for land preparation - Policy for identification and reservation of most } \\
\text { adapted land to coconut cultivation - Land distribution to coconut farmers - Comprehensive program from leasing the land. Prioritize and help } \\
\text { replanting senile plantations- Segmenting the coconut communities within each region for targeted specific products. }\end{array}$ \\
\hline 4 & National policies & $\begin{array}{l}\text { Increase communication between private and public sector and organize better sharing of investments in coconut value chain - Promote } \\
\text { interdependence among the producers and processors - Legislate that processors must offer shareholding in the company to farmers - Promote } \\
\text { cooperative farming - license approved buyers/collectors to cut down the middle man - promote local market for value-added products, revive } \\
\text { local consumption - Segmenting the coconut communities within each region for targeted specific products - Labelling coconut products - } \\
\text { Recruit competent agricultural and extension officers working exclusively on coconut - organize access to financing and micro financing. } \\
\text { Governments to recognize publicize the value of coconut farming and the ease of cultivation after the planting phase. }\end{array}$ \\
\hline 5 & $\begin{array}{l}\text { Diversification for } \\
\text { higher value of } \\
\text { coconut product }\end{array}$ & $\begin{array}{l}\text { Develop the use of by-products (husk and shell) for copra producers - Develop other products than copra and oil - Market germinated coconut } \\
\text { as source of essential fatty acid for preventing human diseases- Promote coconut chips that remains a untapped potential, as snacking is a global } \\
\text { habit amongst all age groups. Providing awareness to the farmers on selling stem and husk for fire wood - Provide a better access of farmers to } \\
\text { market for high value coconut product - Training on improved techniques in processing and marketing - Provision of processing equipment for } \\
\text { Small and Medium scale enterprises with start up capital. }\end{array}$ \\
\hline 6 & $\begin{array}{l}\text { Professionalizing } \\
\text { farmers and their } \\
\text { organizations. }\end{array}$ & $\begin{array}{l}\text { Help farmers increase the productivity of their plantation. Facilitate adoption of innovative techniques - Cooperative farming to reduce the } \\
\text { disadvantages of small plantations - Educate the farmers - Rehabilitation incentives for low productivity farm - Promote existing harvesting } \\
\text { equipment such as coconut sickle or coconut climbing machines. Organize contests between coconut growers with big prices funded by the } \\
\text { government - Create demonstrations sites. }\end{array}$ \\
\hline 7 & $\begin{array}{l}\text { Good cultivation } \\
\text { practices }\end{array}$ & $\begin{array}{l}\text { Shift to organic cultivation - Promote intercropping - Promote irrigation - Subsidy in fertilizers- Promote organic fertilization- Promote the use } \\
\text { of cover crop - Well planned bonus schemes, from land clearing, proper spacing, intercropping, then pay farmers after a } 2 \text { to } 3 \text { year period. }\end{array}$ \\
\hline 8 & Pest and diseases & $\begin{array}{l}\text { Develop biological control - teach farmers to locate and destroy Oryctes breeding sites - Molecular markers for pathogen studies - incentives } \\
\text { for farmers to cut diseased palms and replace them with improved varieties - Subsidies in pesticides and insecticides. }\end{array}$ \\
\hline 9 & $\begin{array}{l}\text { Processing from farm } \\
\text { to consumers }\end{array}$ & $\begin{array}{l}\text { Improve the processes of preparation and storage of high value coconut products - Post harvest management - Develop end to end cold chain } \\
\text { for coconut water - Assist with processing equipment for virgin coconut oil - Developing automation of coconut nectar (toddy) extraction - Set } \\
\text { up small/medium integrated value-added coconut product processing. }\end{array}$ \\
\hline 10 & International policies & $\begin{array}{l}\text { Increase international cooperation in coconut research - Produce training manuals - Long-term loan with technology support to push quality } \\
\text { products to market - Communicate with national health authorities about healthy value of coconut product - Increase links between coconut } \\
\text { growers, scientists, processors, the states and the consumer market. }\end{array}$ \\
\hline 11 & $\begin{array}{l}\text { Reducing cost of } \\
\text { product } \\
\text { transportation }\end{array}$ & Support logistics for freight of coconut products \\
\hline
\end{tabular}




\section{Discussion}

\section{The crucial question of planting material}

In both the brainstorming and the online survey, incentives related to planting material appeared as the main priority. This perfectly supports the first recommendation agreed during the Nadi Meeting, which was:

"National Agricultural Services should allow farmers a primary role in making their own varietal choices, and consider advising against farmers growing only a single coconut variety (Tall, Dwarf, Hybrid, or other). At the national level, agricultural services and other stakeholders should provide farmers with a range of at least six different coconut varieties, including Tall, Dwarf, Compact Dwarf, Hybrid, and eventually composite varieties; and explain to farmers the specificity of each variety regarding environmental adaptation and cultural practices. To reduce overall risk, farmers should be encouraged to plant more than one variety. Local stakeholders (men and women farmers, private enterprises, NGOs and CSOs) should be encouraged to become more involved in supplying quality germplasm. Farmers and other stakeholders should be taught how to autonomously produce quality seedlings of hybrids and other varieties, using the Polymotu concept or any other accepted method."

Most of the participants from the Nadi meeting where in opinion that the planting material should be released free to farmers. A few of them, including the first author of this text, think that such an incentive is not always efficient: at least in some cases, farmers give little importance and take little care of seednuts and seedlings that are delivered free of charge. Moreover, it may jeopardize the development of a private market for coconut seednuts and seedlings. In some countries as for instance India, private companies are selling hybrid seednuts. These private companies have many customers and make good profit. Sometimes, Indian farmers have to wait six month to get their seednuts because of over demand.

At least part of these incentives could be conditional on the farmer achieving tangible results, such as the survival and proper maintenance of the new coconut palms. This requires more accurate and time-consuming monitoring of activities by agricultural officers. This also supports more effectively the farmers who benefit from better advices. For instance, the farmers could pay 0.5 USD per seedling, and then could receive an incentive of 0.5 USD per coconut palm remaining alive six month later, and another incentive of one USD for coconut palms remaining alive and in good condition two years later. The solution undertaken in India, where half of the cost in taken in charge,

In case of organic cultivation, a practical solution seems to link these assessments to the regular visit conducted for monitoring and certifying the organic status of the farms. As officers are visiting yearly the farms for organic certification purposes, the checking of new planting can be conducted during these visits. This kind of organisation is already running in the Solomon Islands by officers of the company Kokonut Pacific. Moreover, it allows the constitution of farmer's database that will give a real appraisal of the efficiency of these incentives and the linked development programs.

\section{About donation and tradition}

In traditional societies, in which most people interactions remain presential and not virtual, it seems that purely philanthropic acts are rare; when the gift is practiced, an intangible return is usually expected in terms of social benefit: the gift publicly values the donor, contributes to generating positive interactions or easing tensions.

In projects of limited duration, if the seeds are delivered free of charge, the gift must be presented as connected to its social context and rather formulated in terms of exchange: the seeds are given, but in exchange the farmers undertake to respect good management practices, and to provide information and feedback. In this case, the management practices and information return required from farmers should be clearly expressed. It may or may not be the subject of a written and signed contract. The levels and methods of such contracting require to be studied and optimized according to the different cultural 
contexts and may engage social players such as traditional chiefs and leaders, as recommended by the participants of our meeting.

\section{Which farmers to subsidy in priority?}

The examples of Fiji and Solomon Islands seems to suggest this prioritization: first, the farmers who already provides their production to the coconut industry (be it small or large transformation units), or are marketing highvalue products by themselves. Second, the youths and new farmers. Third, farmers who would like to shift their cultivation from sugar cane, oil palm or other tree crops to coconut; but for these one, well conducted demonstration plots and the guarantee of having a market will be needed for convincing them shifting to coconut cultivation.

\section{Incentives orientated towards multicropping systems}

The Nadi meeting recognized the importance of intercropping with a diversity of species, which are already being used by farmers, such as coffee, kava, cocoa, banana, noni, pineapple, fruit crops and vegetables for food security. Ministry of Agriculture and others should provide specific recommendations adapted to land capability regarding the best species to intercrop.

Incentives such as one of the "stimulus packages" developed in Samoa seems particularly interesting: the selected farmers have to pay 100 WST to join the program, and then receive free planting material and advices. An interesting aspect is that this does not restrict to coconut, but include also cocoa and other tree crops. Thus, it is not limited to one crop species and takes into account the farm in a more integrated and holistic way (Burgess, 2017).

What could also be free is assistance for installing a leguminous cover crop in coconut plantations. Such cover crop can fix naturally up to $100 \mathrm{~kg}$ of nitrogen per hectare. Our feeling is that in the pacific region, farmers are killing themselves to weed manually wild plants that are growing and invading plantations very quickly. This weeding is extremely gruelling and discourages many planters who abandon their coconut groves and sometimes do not even harvest the fruits. Shared land cleaning machinery could also be an effective incentive.

Regarding incentives on providing mineral fertilization, insecticides and herbicides, some participants were in opinion that such programmes should take into account environmental effects and degradation of soils. Balance is needed between providing subsidies and maintaining quality of products and environment. Biocontrol of pests and diseases should be favoured.

\section{Conclusion}

The writing of this text was completed in November 2018, so about 6 and 3 months after respectively the Nadi CIDP Meeting and the COCOTECH conference. It seems that the momentum generated by CIDP and COCOTECH has had a strong positive effect. In the end of August 2018, the Fijian government launched a new and important incentive program for coconut farmers. Under the Ministry of Public Enterprises 2018/2019 National Budget, FJ\$700,000 has been allocated for coconut development to Copra Millers of Fiji Ltd, with the target to plant 30,000 coconut seedlings in the first year. The Copra Millers Board chairperson explained that the qualified farmers will receive FJ $\$ 10$ for successfully grown coconut seedlings after the first three months and another FJ $\$ 10$ for each healthy seedling after six months (Rawailai, 2018).

This paper addressed only partially the question of incentives for boosting coconut production. It is necessary to continue and refine this first analyse, and try to compare the effectiveness of the different incentives used so far. In general, there is a lack of systematic data collection from farmers to assess the real effectiveness of these measures. Any new incentive measure should therefore incorporate the tools that will make it possible to evaluate its effectiveness. In order to better assess and to boost the coconut value chain, the Nadi meeting recommended agricultural services create and/or strengthen national coconut farmer's databases and create well-documented coconut parent palm databases by using the method and datasheets 
recently developed by R. Bourdeix, V. Kumar and V. Mataora (Bourdeix et al., 2018c). These databases should be conceived and implemented to link with other existing farmer's databases. They should also integrate with Geographical Information Systems.

This first study would also need to be pursued by analysing more dedicated national policies. Probably the most important incentive is linked to communication with farmers. Relevant ministries should make the relevant technical information fully available for farmers; they should ensure that a maximum of them will be aware of this information, will read it, will believe it and will use it.

A crucial incentive is for government to subsidize coconut research, and in particular national coconut breeding programmes that will allow farmers to access diverse planting material. The Nadi meeting noted that nothing could replace well-designed, regular and sustainable breeding programs conducted by well-trained professionals. Expertise is needed to assess the coconut breeding programs presently existing in the Pacific Region; to help developing local skills; to create new programmes and to facilitate international collaboration between these programmes.

\section{References}

Bourdeix, R., Hussein N., and Dore, D. (2018a) Technical recommendations from the CIDP meeting on Coconut Production and Seeds Systems in the Pacific Region held from 7 to 20 April 2018 in Nadi, Fiji. In: Bourdeix, R., Labouisse, J.P., Mapusua, K., Ollivier, J. and Kumar, V. (2018). Coconut planting material for the Pacific Region. Available at the URL: https://replantcoconut.blogspot.com. Seen on 09/11/2018.

Bourdeix, R. (2018b). Report for Fiji in the framework of the expertise on coconut production and seed system (SPC/CIDP/PRAG 07), CIDP (Coconut Industry Development for the Pacific Region). Internal report, Secretariat of the South Pacific Community, 28 p.
Bourdeix, R., Kuma, V. and Mataroa, V. (2018c) Recommended method for selecting good parent palms and producing Tall-type coconut seednuts. In: Bourdeix, R., Labouisse, J.P., Mapusua, K., Ollivier, J. and Kumar, V. (2018). Coconut planting material for the Pacific Region. Available at

the URL: https://replantcoconut.blogspot.com. Seen on 09/11/2018.

Burgess, R.J. (2017). The Intercropping of Smallholder Coconuts in Western Samoa: an analysis using multi-stage linear programming. Canberra, ACT: Development Studies Centre, The Australian National University.

Coconut Development Board. (2018). Schemes of Coconut Development Board. Available at the URL: http://coconutboard.nic.in/Scheme.aspx\# Production. Seen $19^{\text {th }}$ August 2018.

Krisanapook, K. (2015) Thailand's banana, coconut, mango and papaya industries: a country report. Available at the URL: http://www.fftc.agnet.org/files/lib_articles/ 20150731150149/1.\%20Thailand.pdf. Seen on $26 / 10 / 2018$.

Powell, A., Bond, S. (2018). USDA Provides Almost \$70 Million in Fiscal Year 2018 to Protect Agriculture and Plants from Pests and Diseases through the 2014 Farm Bill Section 10007. Available at the URL: https://www.aphis.usda.gov/aphis/newsroo m/news/sa_by_date/sa-2018/fy18-farmbill-funding. Seen on 26/10/2018.

Rawalai, L. (2018). Search for coconut seeds. The Fiji Time online. 13 August 2018. Available at the URL: http://www.fijitimes.com/search-forcoconut-seeds. Seen on 26/10/2018.

Wijenayake, T. (2017). Coconut crisis - can drip irrigation save the industry? DailyFT, seen at the URL: http://www.ft.lk/columns/Coconut-crisis$\%$ E2\%80\%93-can-drip-irrigation-savethe-industry-/4-645548 on 19th August 2018 . Seen on $26 / 10 / 2018$. 
Tuiletufuga, N.L. (2016). Govt. resurrects Stimulus package. Savali Newspaper, Jun 13 2016. Available at the URL: http://www.iniinisamoa.com/2016/06/13/g ovt-resurrects-stimulus-package. Seen on 26/10/2018.

\section{Further readings}

Abd, R. H., Che, H. H., \& Mohamad, I. (2010). Replanting and rehabilitation of coconut under smallholders. Planter, 86(1009), 243-252.

Catacutan, D.C., \& Duque-Piñon, C. (2008). The policy environment of vegetable agroforestry in the Philippines: Are there incentives for small farmers?

Catacutan, D.C., Ha, D.T., Duque-Piñon, C., \& Loan, L.T. (2009). The policy environment of vegetable-agroforestry in the Philippines and Vietnam: A scoping study. Malabalay City, Philippines: World Agroforestry Centre (ICRAF-Philippines).

Chomitz, K.M., \& Griffiths, C. (1996). Deforestation, shifting cultivation, and tree crops in Indonesia: nationwide patterns of smallholder agriculture at the forest frontier. Poverty, Environment, and Growth. World Bank, Washington DC. [Accessed online 2004.].

Clarete, R.L., \& Roumasset, J.A. (1983). An analysis of the economic policies affecting the Philippine coconut industry. Abd, R. H., Che, H.H., \& Mohamad, I. (2010). Replanting and rehabilitation of coconut under smallholders. Planter, 86(1009), 243252.

David, C.C. (1995). Economic policies and agricultural incentives: the Philippine case (No. DP 1995-15). Manila: Philippine Institute for Development Studies.

Duhamel, G. (1993). Production and dissemination of improved coconut cultivars EEC-Pacific Regional Agricultural Program (PRAP). In ACIAR PROCEEDINGS (pp. 19-19). Australian Centre for International Agricultural Research.

Garcia, J.N.M., Aguilar, E. A., Sangalang, J.B., Alcantara, A.J., Habito, R.C.F., Medina,
C.P., \& Malayang III, B.S. (2009). Valuation of ecosystem services of coconut types: framework and methodology development. Journal of Environmental Science and Management, 12(1).

Godoy, R.A. (1992). Determinants of smallholder commercial tree cultivation. World Development, 20(5), 713-725.

Karim, S., \& Harrison, S. (2016). Promoting sustainable agriculture and agroforestry to replace unproductive land use in Fiji and Vanuatu. Australian Centre for International Agricultural Research (ACIAR).

Mustapha, Z.H. (1983). Some Observations on Incentive Policies in Malaysian Agriculture and Implications on Growth and Equity in the Smallholder Sector. Akademika, 23(1).

Mwinjaka, S., Chiduza, C., Temu, A.E., Sukume, C., \& Diehl, L. (1999). Coconut palm replacement model for Tanzanian farming systems. Journal of Agricultural Economics and Development, 3, 61-70.

Newman, S.M. (1985). A survey of interculture practices and research in Sri Lanka. Agroforestry systems, 3(1), 25-36.

Pabuayon, I.M., Medina, S. M., Medina, C.M., Manohar, E.C., \& Villegas, J.I.P. (2008). Economic and environmental concerns in Philippine upland coconut farms: an analysis of policy, farming systems and socioeconomic issues. Economy \& Environment Program for Southeast Asia, IDRC-CRDI, Singapore.

Pande, S.K., \& Pandey, D. (2004). Impact of incentives on the development of forest plantation resources in India. What does it take, 81-102.

Pehaut, Y. (1990). Les plantations allemandes des mers du sud avant 1914 (No. 12). Presses Univ de Bordeaux.

Walter, M.A. (1978). The conflict of the traditional and the traditionalised: an analysis of Fijian land tenure. The Journal of the Polynesian Society, 87(2), 89-108.

Waragoda, W.K.D.J. (1978). Financial incentives for the maintenance. 
Cord 2018, 34 (1) 